\title{
VẬN DỤNG TỦ TƯởNG HỒ CHÍ MINH VỀ XÂY DỬNG ĐẢNG TRONG TÁC PHẨM SỬA ĐỔI LỐI LÀM VIỆC ĐỄ XÂY DỤ̉NG ĐẢNG TRONG SẠCH, VŨ̉NG MẠNH
}

\author{
ĐẶNG THI MINH PHƯỢNG, LÊ THANH HÒA \\ Khoa Lý luận Chính trị,Truờng Đại học Công nghiệp Thành phố Hồ Chi Minh \\ dangthiminhphuong@iuh.edu.vn
}

Tóm tắt. Năm 1947, Chủ tịch Hồ Chí Minh viết tác phẩm Sỉa đổi lối làm việc, ký bút danh X.Y.Z. Cuốn sách do Nhà xuất bản Sự thật xuất bản lần đầu tiên vào đầu năm 1948. Nội dung tác phẩm đề cập đến nhiều vấn đề về xây dựng và chỉnh đốn Đảng, rèn luyện cán bộ, đảng viên về đạo đức cách mạng và phong cách công tác. Trong bài viết này, tác giả tập trung phân tích một số nội dung cơ bản của tác phẩm Sưa đổi lối làm việc và sự vận dụng tư tưởng Hồ Chí Minh về xây dựng Đảng trong tác phẩm của Đảng Cộng sản Việt Nam để xây dựng Đảng trong sạch, vững mạnh.

Từ khóa: Tư tưởng Hồ Chí Minh, xây dựng Đảng, cán bộ, đảng viên.

\section{APPLYING HO CHI MINH IDEOLOGY ON PARTY BUILDING IN THE WORK "SUA DOI LOI LAM VIEC" TO BUILD A CHASTE AND POWERFUL PARTY}

\begin{abstract}
In 1947, President Ho Chi Minh wrote the work "Sua doi loi lam viec", under the pseudonym X.Y.Z. The book was first published by "Su that" publisher in early 1948. The book mentioned many issues about building and regulating the Party, training cadres, party members about revolutionary morality and working style. In this article, the authors focus on analyzing some basic contents of the work "Sua doi loi lam viec" and application of Ho Chi Minh ideology in building Party in working by Viet Nam Communist Party in order to build a chaste and powerful Party.
\end{abstract}

Key words. Ho Chi Minh ideology, Party building, cadres, Party members.

\section{1. ĐẠTT VẤN ĐỀ}

Chủ tịch Hồ Chí Minh luôn quan tâm, chăm lo công tác xây dựng, củng cố Đảng, giáo dục, rèn luyện đạo đức cách mạng cho đội ngũ cán bộ, đảng viên, xây dựng đội ngũ cán bộ có đủ đức, đủ tài để Đảng là tổ chức tiêu biểu cho trí tuệ, đạo đức, lương tâm và danh dự của dân tộc. Tại chiến khu Việt Bắc, Chủ tịch Hồ Chí Minh viết tác phẩm Sưa đổi lối làm viẹc. Tác phẩm Sưa đổi lối làm việc được phổ biến rộng rãi trong toàn quốc có ý nghĩa định hướng cuộc vận động xây dựng, chỉnh đốn Đảng để Đảng thực sự nâng cao năng lực lãnh đạo, nâng cao uy tín, đạo đức và sự gắn bó máu thịt với nhân dân, lãnh đạo nhân dân vượt qua mọi khó khăn, gian khổ giành thắng lợi trong cuộc kháng chiến chống thực dân Pháp xâm lược. Vận dụng tư tưởng Hồ Chí Minh về xây dựng, chỉnh đốn Đảng trong tác phẩm Sửa đổi lối làm việc, toàn Đảng, toàn dân, toàn quân ta đang triển khai thực hiện Nghị quyết Trung ương 4 , khóa XII về tăng cường xây dưng, chỉnh đốn Đảng; ngăn chặn, đẩy lùi sự suy thoái về tu tuởng chính trị, đạo đức, lối sống, nhũng biểu hiện "tụ diễn biến", "tư chuyển hoá” trong nội bộ gắn với thực hiện Quy định số 08QĐi/TW của Ban Chấp hành Trung ương về trách nhiệm nêu guơng của cán bộ, đảng viên, truớc hết là Ủy viên Bộ Chính trị, Úy viên Ban Bí thu, Ủy viên Ban Chấp hành Trung uoong, tiến tới chuẩn bị đại hội đảng bộ các cấp và Đại hội XIII của Đảng.

\section{NỘI DUNG NGHIÊN CÚU}

\subsection{Hoàn cảnh lịch sử ra đời của tác phẩm}

Sau Cách mạng Tháng Tám năm 1945, nước Việt Nam Dân chủ Cộng hòa ra đời. Mới ra đời, chính quyền của nước Việt Nam Dân chủ Cộng hòa phải đương đầu với nhiều khó khăn thử thách về thù trong, giặc ngoài, giặc đói, giặc dốt. Ngày 23/9/1945, Pháp nổ súng tấn công Sài Gòn-Gia Định mở đầu cuộc chiến tranh Pháp-Việt lần thứ hai. Dưới sự lãnh đạo của Đảng, đứng đầu là Chủ tịch Hồ Chí Minh, nhân dân Việt Nam một mặt ra sức khắc phục những khó khăn về chính trị, kinh tế, văn hóa xã hội; mặt khác, khẩn trương tiến hành chuẩn bị lực lượng đối phó với nguy cơ cuộc chiến tranh mở rộng trên phạm vi cả 
nước của thực dân Pháp. Trong điều kiện Đảng trở thành Đảng cầm quyền, từ năm 1945 đến năm 1947, Chủ tịch Hồ Chí Minh viết nhiều bài với mục đích xây dựng tổ chức Đảng trong sạch, vững mạnh, tạo ra một đội ngũ cán bộ đảng viên gương mẫu về đạo đức cách mạng, trở thành những "cán bộ mà biết làm cho dân tin, dân phục, dân yêu" như: Sao cho được lòng dân? (12/10/1945), Thu gửi Ủy ban nhân dân các kỳ, tỉnh, huyện và làng (10/1945), Thu gưi các đồng chí Bắc Bộ (3/1947), Thu gưi các đồng chí Trung Bộ (1947) Cán bộ tốt và cán bộ xoàng (6/1947). Trong những bài viết trên, nhiều căn bệnh của đội ngũ cán bộ, đảng viên về lề lối làm việc, tác phong, đạo đức cách mạng như: Địa phương chủ nghĩa, óc bè phái, óc quân phiệt quan liêu, óc hẹp hòi, ham chuộng hình thức, vô kỷ luật, kỷ luật không nghiêm, ích kỷ, hủ hóa... được Chủ tịch Hồ Chí Minh chỉ rõ. Những hạn chế trên nếu chậm khắc phục sẽ ảnh hưởng tới uy tín của Đảng và sự nghiệp cách mạng. Là người lãnh đạo tối cao của dân tộc, Chủ tịch Hồ Chí Minh hiểu rõ hơn ai hết những khuyết điểm, "căn bệnh" còn tồn tại trong Đảng. Do vậy, để hoàn thành trọng trách lãnh đạo của mình, Đảng phải được xây dựng và chỉnh đốn để thực sự nâng cao năng lực lãnh đạo, nâng cao uy tín đạo đức và sự gắn bó máu thịt của Đảng, chính quyền với nhân dân. Nếu không làm tốt công tác củng cố, xây dựng, chỉnh đốn Đảng, uy tín của Đảng, của cán bộ đảng viên sẽ giảm sút thậm chí ảnh hưởng đến sự tồn vong của quốc gia dân tộc: "1. Trong lúc dân tộc đang ở ngã tư đường, chết hay sống, mất hay còn, mỗi đồng chí và toàn cả đoàn thể phải đem tất cả tinh thần và lực lượng ra để đưa toàn dân quay về một hướng, nhằm vào một mục đích: đánh đuổi thực dân Pháp và làm cho nước thống nhất và độc lập. Vì vậy mỗi một đồng chí và toàn cả đoàn thể phải: sáng suốt, khôn khéo, cẩn thận, kiên quyết, siêng năng, nhất trí. 2. Cuộc trường kỳ kháng chiến này tức là dân tộc cách mệnh đến trình độ tối cao. Trong lúc này tư tưởng và hành động của mỗi một đồng chí rất có quan hệ đến toàn quốc. Nếu một người sơ suất, một việc sơ suất là có thể hỏng việc to; sai một ly đi một dặm" [4; 87]. Đến giữa năm 1947, những khuyết điểm, sai lầm của đội ngũ cán bộ, đảng viên trong bộ máy của Đảng và Chính phủ được Chủ tịch Hồ Chí Minh chỉ rõ trong các bài viết vẫn chậm hoặc chưa được sửa chữa, khắc phục. Chính vì vậy, để tăng cường chỉ đạo công tác xây dựng, chỉnh đốn Đảng, nâng cao năng lực lãnh đạo, uy tín và đạo đức của Đảng trước nhân dân; đề cao và khẳng định sự gắn bó máu thịt giữa Đảng, chính quyền với nhân dân, tại xã Điềm Mặc, huyện Định Hóa, tỉnh Thái Nguyên, Chủ tịch Hồ Chí Minh viết tác phẩm Sứa đổi lối làm việc. Cuối năm 1947, tác phẩm được hoàn thiện. Từ khi ra đời đến nay, tác phẩm Sứa đổi lối làm việc luôn là văn kiện quan trọng trong công tác xây dựng Đảng trên các phương diện chính trị, tư tưởng, tổ chức, về huấn luyện, đào tạo, sử dụng, chính sách đối với cán bộ của Đảng cầm quyền.

\subsection{Một số nội dung cơ bản của tác phẩm Sửa đổi lối làm việc về công tác xây dựng Đảng}

Từ chủ đề chính là xây dựng, chỉnh đốn Đảng, tác phẩm Sưa đổi lối làm việc đề cập đến 6 vấn đề cơ bản, cấp bách của Đảng và đảng viên: 1 . Phê bình và sửa chữa, 2 . Mấy điều kinh nghiệm, 3 . Tư cách và đạo đức cách mạng; 4. Vấn đề cán bộ; 5 . Cách lãnh đạo; 6 . Chống thói ba hoa. Những nội dung của tác phẩm thể hiện rõ tư tưởng của Chủ tịch Hồ Chí Minh về những vấn đề lớn trong công tác xây dựng đảng cầm quyền. Tác phẩm còn là cẩm nang cho cán bộ, đảng viên trong học tập, phẩn đấu công tác, tu dưỡng đạo đức và rèn luyện tác phong làm việc.

\subsubsection{Phê bình và sửa chữa để xây dựng và phát triển Đảng}

Theo Chủ tịch Hồ Chí Minh, tự phê bình và phê bình là quy luật phát triển của Đảng, là vũ khí để xây dựng Đảng trong sạch, vững mạnh. Mở đầu tác phẩm Sưa đổi lối làm việc, Chủ tịch Hồ Chí Minh đề cập đến vấn đề phê bình và sửa chữa lối làm việc, ý nghĩa, tầm quan trọng của việc phê bình. Chủ tịch Hồ Chí Minh chủ trương phải phê bình và sửa chữa để khắc phục khuyết điểm, vì có tẩy sạch khuyết điểm, công việc mới có thể tiến bộ. Mục đích của việc phê bình cũng như cách phê bình cốt để giúp nhau sửa chữa, giúp nhau tiến bộ. Cốt để sửa đổi cách làm việc cho tốt hơn, đúng hơn. Cốt đoàn kết và thống nhất nội bộ [4; 272]. Do đó, mỗi cán bộ, đảng viên trong Đảng hàng ngày phải kiểm điểm, tự phê bình, sửa chữa như rửa mặt hàng ngày. Chỉ trên cơ sở giúp nhau sửa chữa khuyết điểm, phát huy ưu điểm, để cùng nhau tiến bộ thì cách mạng mới sớm thành công. Để Đảng trở nên trong sạch, vững mạnh, phê bình và tự phê bình là "vũ khí sắc bén", là "quy luật" phát triển của Đảng. Nếu không kiên quyết thực hiện phê bình và tự phê bình thì cũng giống như giấu giếm bệnh tật trong người. Bệnh mà không uống thuốc, không trị bệnh thì càng nặng, ảnh hưởng trực tiếp đến sức khỏe, tính mạng của con người. Đối với Đảng cầm quyền mà giấu giếm khuyết điểm là một Đảng hỏng, một Đảng có gan thừa nhận những khuyết điểm của mình, vạch rõ khuyết điểm từ đâu mà có đồng thời kiên quyêt sửa chữa sai lầm khuyết điểm mới là Đảng chân chính, 
cách mạng. Đảng cần phải biết những ưu điểm và khuyết điểm của mình để dạy dỗ đảng viên, dạy dỗ quần chúng. Sợ phê bình, tức là "quan liêu hoá", tức là tự mãn tự túc, tức là "mèo khen mèo dài đuôi". Nhưng trong khi phê bình cần có thái độ "thành thật", có "lòng nhân ái", phải "công khai". Phê bình không phải "để xoi mói”, tránh thái độ "bưng mắt bắt chim", thái độ "giấu bệnh sợ thuốc", không thật thà, không đúng đắn. Phê bình không phải để "công kích, để nói xấu, để chửi rủa" [4; 301]. Vì vậy, Chủ tịch Hồ Chí Minh yêu cầu cần có thái độ đúng đắn khi phê bình mình cũng như phê bình người. Khi phê bình phải ráo riết, triệt để, thật thà, không nể nang, không thêm bớt. Phải vạch rõ cả ưu điểm và khuyết điểm. Đồng thời, chớ dùng những lời mỉa mai, chua cay, đâm thọc. Phê bình việc làm, chứ không phải phê bình người. Những người bị phê bình thì phải vui lòng nhận xét để sửa đổi, không nên vì bị phê bình mà nản chí, hoặc oán ghét”[4; 272].

Từ việc chỉ ra yêu cầu của việc phải thực hành phê bình trong Đảng, Chủ tịch Hồ Chí Minh, nêu lý do của việc phải sửa đổi lối làm việc trong Đảng. Vào thời điểm năm 1947, Đảng đã trở là đảng cầm quyền. Nhưng trước đó, ngày 11/11/1945, Ban Chấp hành Trung ương Đảng Cộng sản Đông Dương ra Thông cáo "Tự ý giải tán". Tuyên bố "Tự ý giải tán", nhưng thực chất Đảng rút vào hoạt động bí mật, tiếp tục lãnh đạo cách mạng. Để công khai tuyên truyền chủ nghĩa Mác-Lênin, đường lối, chủ trương của Đảng, Đảng lập ra Hội Nghiên cúu chủ nghĩa Mác ở Đông Dương. Đảng có vai trò quan trọng của Đảng trong phong trào cách mạng nước nhà. "Đảng ta hy sinh tranh đấu, đoàn kết, lãnh đạo nhân dân, tranh lại thống nhất và độc lập. Công việc đã có kết quả vẻ vang" [4;272] nhưng, nếu mỗi cán bộ, mỗi đảng viên làm việc đúng hơn, khéo hơn, thì thành tích của Đảng còn to tát hơn nữa. Do đó, Chủ tịch Hồ Chí Minh yêu cầu, phải sửa đổi ngay lối làm việc của Đảng, vì chỉ có sửa đổi lối làm việc của mình Đảng mới chóng phát triển, công việc mới chóng thành công. Chỉ khi sửa đổi lối làm việc hiện tại của mình, Đảng mới có thể lãnh đạo sự nghiệp cách mạng của nhân dân, đi đến thắng lợi cuối cùng. Đảng mới có thể giữ vai trò lãnh đạo của mình trong tiến trình cách mạng. Nhưng để sửa đổi được thì trước hết mỗi người, mỗi cán bộ, đảng viên phải nhận thức rõ căn bệnh mà mình đang mắc phải. Xác định được điều đó, Chủ tịch Hồ Chí Minh, đã chỉ ra ba chứng bệnh rất nguy hiểm trong Đảng cần phải sửa chữa ngay, đó là bệnh chủ quan, bệnh hẹp hòi và ba hoa. Ba chứng bệnh này rất nguy hiểm.

Bệnh chủ quan, là "khuyết điểm về tư tưởng" [4;272]. Theo Chủ tịch Hồ Chí Minh, nguyên nhân của bệnh chủ quan là kém lý luận, khinh lý luận hoặc lý luận suông. Chủ tịch Hồ Chí Minh chỉ ra đây là chứng bệnh nguy hiểm gây tác hại lớn cho cách mạng. Vì mắc bệnh chủ quan, cán bộ, đảng viên thường giải quyết công việc xuất phát từ ý muốn chủ quan, mà không căn cứ vào điều kiện cụ thể và quy luật khách quan. Do "gặp mọi việc không biết xem xét cho rõ, cân nhắc cho đúng, xử trí cho khéo. Không biểt nhận rõ điều kiện hoàn cảnh khách quan, ý mình nghĩ thế nào làm thế ấy. Kết quả thường thất bại" [4; 272]. Người mắc bệnh chủ quan đều coi khinh lý luận, làm việc chỉ theo kinh nghiệm của bản thân, không biết khái quát thành lý luận chung, giải quyết công việc một cách sự vụ, vụn vặt. Đó là bệnh kinh nghiệm chủ nghĩa. Chủ nghĩa kinh nghiệm chính là một biểu hiện của chủ nghĩa chủ quan. Xuất phát từ sự phân tích trên, Chủ tịch Hồ Chí Minh yêu cầu "mỗi cán bộ, mỗi đảng viên phải học lý luận, lý luận áp dụng vào công việc thưc tế. Phải chữa cái bệnh kém lý luận, khinh lý luận và lý luận suông" [4; 274-275].

Bệnh hẹp hòi là "khuyết điểm về quan hệ trong Đảng với ngoài Đảng" [4; 273]. Chủ tịch Hồ Chí Minh nhận định bệnh hẹp hòi là căn bệnh rất nguy hiểm, mà nhiều cán bộ và đảng viên còn mắc phải. Bệnh hẹp hòi: "Trong, thì bệnh này ngăn trở Đảng thống nhất và đoàn kết. Ngoài, thì nó phá hoại sự đoàn kết toàn dân. Nhiều thứ bệnh, như chủ nghĩa địa phương, chủ nghĩa bản vị, chủ nghĩa cá nhân, khuynh hướng tham danh vọng, tham địa vị, dìm người giỏi, bệnh hủ hoá, v.v., đều do bệnh hẹp hòi mà ra!" [4; 276]. Vì bệnh hẹp hòi mà "có những cán bộ chỉ thấy lợi ích bộ phận của mình, không thấy lợi ích của toàn thể, muốn đem lợi ích của toàn thể phục tùng lợi ích của bộ phận mình", "Vì bệnh hẹp hòi mà không biết dùng nhân tài (...). Cũng vì bệnh hẹp hòi mà không biết cách xử trí khôn khéo với các hạng đồng bào" [4; 278]. Cách tốt nhất để chữa căn bệnh hẹp hòi được Chủ tịch Hồ Chí Minh là tự phê bình ráo riết và phải lấy lòng nhân ái, lấy lòng thành thật, mà ráo riết phê bình đồng chí mình. Hai việc đó phải đi đôi với nhau. Trong lúc phê bình khuyết điểm phải vạch ra rõ ràng, và ưu điểm cũng phải nhắc đến. Một mặt là để sửa chữa cho nhau. Một mặt là để khuyến khích nhau, Nếu làm được tốt phê bình thì trong Đảng sẽ không có bệnh, Đảng sẽ mạnh khỏe vô cùng.

Thói ba hoa là khuyết điểm về cách nói và cách viết [4; 273]. Chủ tịch Hồ Chí Minh nhấn mạnh: Chống thói ba hoa phải đồng hành với chống bệnh chủ quan và bệnh hẹp hòi. Thói ba hoa là "bạn đường", là 
"bạn tri kî" của bệnh chủ quan và bệnh hẹp hòi”, "Thói ba hoa còn, tức là bệnh chủ quan và bệnh hẹp hòi cũng chưa khỏi hẳn" [4; 339]. Chủ tịch Hồ Chí Minh chỉ đích danh các biểu hiện của thói ba hoa mà cán bộ, đảng viên thường mắc phải: Dài dòng, rỗng tuếch, cầu kỳ, khô khan, lúng túng, báo cáo lông bông, lụp chụp, cẩu thả, sáo cũ, nói không ai hiểu, hay nói chữ. Những căn bệnh này nếu chúng ta không biết thì một ngày nào đó nó sẽ phát triển thành những căn bệnh lớn hơn gây hại cho xã hội, chính vì vậy cán bộ cần nghiêm túc thẳng thắn xem lại chính mình để sửa chữa những lỗi mà mình gặp phải nếu không căn bệnh đó sẽ gây hại to lớn cho công việc của Đảng. Thói ba hoa có gây ra nhiều tác hại, khi nó chưa gây ra sai lầm lớn thì vẫn có thể coi là chuyện bình thường, nhưng khi nó tạo ra sai lầm thì khó mà sửa chữa được. Chính vì thế phải chữa thói ba hoa ngay khi nó mới hình thành. Chủ tịch Hồ Chí Minh "kê đơn" 5 liều thuốc chữa thói ba hoa. Mỗi cán bộ, đảng viên nếu "uống thuốc" đúng thì thói ba hoa sẽ bớt dần, tư cách của cán bộ và đảng viên theo đó mà tăng lên.

Như vậy, với những câu văn ngắn gọn, hàm súc, lời văn gần gũi với quần chúng, dễ đọc, dễ hiểu, tác phẩm Sưa đổi lối làm việc, đã thể hiện được những tư tưởng cơ bản của Chủ tịch Hồ Chí Minh về xây dựng và chỉnh đốn Đảng, đóng góp những giá trị lý luận và thực tiễn sâu sắc cho công tác rèn luyện cán bộ, đảng viên của Đảng ta ở mọi thời kì phát triển của đất nước cả trong hiện tại và tương lai.

\subsubsection{Tư cách và đạo đức cách mạng của Đảng}

Chủ tịch Hồ Chí Minh nhấn mạnh tư cách của Đảng chân chính cách mạng gồm 12 tiêu chí: "1. Đảng không phải là một tổ chức để làm quan phát tài. Nó phải làm tròn nhiệm vụ giải phóng dân tộc, làm cho Tổ quốc giàu mạnh, đồng bào sung sướng. 2. Cán bộ của Đảng phải hiểu biết lý luận cách mạng, và lý luận cùng thực hành phải luôn luôn đi đôi với nhau (...) Đảng phải luôn luôn xét lại những nghị quyết và những chỉ thị của mình đã thi hành thế nào" [4;290]. Trong điều kiện Đảng trở thành Đảng cầm quyền theo Người: Muốn cho Đảng được vững bền. Mười hai điều đó chớ quên điều nào. Phận sự của đảng viên và cán bộ của Đảng là trọng lợi ích của Đảng, đặt lợi ích của Đảng lên trên hết, trước hết. Trong hoàn cảnh nào, việc gì, đảng viên và cán bộ cũng cần đặt lợi ích của cá nhân sau lợi ích của Đảng. Người cán bộ phải tuyệt đối trung thành với Đảng, với Tổ quốc, với sự nghiệp cách mạng của nhân dân. Lòng trung thành hoàn toàn xa lạ với sự hoang mang, dao động thậm chí là phản bội đi ngược lại lợi ích chung của Đảng, của dân tộc. Mỗi cán bộ, đảng viên trước khi thực hiện bất kỳ nhiệm vụ gì cũng phải trả lời câu hỏi: Vì ai mà làm? Đối với ai phụ trách? Chính phủ và Đảng chỉ mưu cầu hạnh phúc cho nhân dân, vì thế bất cứ việc gì cũng là vì lợi ích của nhân dân mà làm. Do đó, cán bộ, đảng viên phải chịu trách nhiệm trước nhân dân, luôn vì lợi ích của nhân dân. Người cán bộ cần có đạo đức cách mạng. Đạo đức cách mạng theo Chủ tịch Hồ Chí Minh là đạo đức mới, là gốc, là nền tảng nuôi dưỡng và phát triển con người. Đạo đức cách mạng không phải vì danh vọng cá nhân, mà vì lợi ích chung của Đảng, của dân tộc, của loài người: "Cũng như sông thì có nguồn mới có nước, không có nguồn thì sông cạn. Cây phải có gốc, không có gốc thì cây héo. Người cách mạng phải có đạo đức, không có đạo đức thì dù tài giỏi mấy cũng không lãnh đạo được nhân dân. Vì muốn giải phóng cho dân tộc, giải phóng cho loài người là một công việc to tát, mà tự mình không có đạo đức, không có căn bản, tự mình đã hủ hoá, xấu xa thì còn làm nổi việc gì?" [4; 292-293]. Với tinh thần đó, đạo đức cách mạng, là một nguồn động lực giúp cán bộ vượt qua mọi khó khăn, cám dỗ trên con đường cách mạng không ít chông gai, thử thách. Trong tác phẩm Sưa đổi lối làm việc, Người khái quát và đi sâu phân tích năm chữ Nhân, Nghĩa, Trí, Dũng, Liềm. Trong công tác xây dựng Đảng để Đảng thật sự vững mạnh để xứng đáng là Đảng cầm quyền, thì mỗi cán bộ, đảng viên của Đảng phải thực sự "thấm nhuần đạo đức cách mạng, thật sự cần kiệm liêm chính, chí công vô tư". Có những phẩm chất cách mạng trên làm nền tảng thì khi gặp khó khăn, gian khổ, thất bại, cũng không sợ sệt, rụt rè, lùi bước. Là người sáng lập và rèn luyện Đảng, đứng đầu nhà nước, Chủ tịch Hồ Chí Minh rất coi trọng vấn đề kỷ luật trong Đảng. Kỷ luật của Đảng là kỷ luật tự giác. Chủ tịch Hồ Chí Minh chỉ rõ: Không ai bắt buộc ai vào Đảng làm chiến sĩ xung phong. Đó là do sự tự giác, lòng hăng hái của mỗi người mà tình nguyện làm đảng viên, làm chiến sĩ xung phong. Đã vậy, thì mỗi người đảng viên phải cố gẳng cho xứng đáng là một người trong những người đại biểu của dân tộc. Do đó, ở bất kỳ hoàn cảnh nào, đảng viên và cán bộ cần phải luôn luôn ra sức phấn đấu, ra sức làm việc, cố gắng học tập để nâng cao trình độ văn hóa, trí thức và chính trị của mình. Luôn luôn giữ kỷ luật xứng đáng là một người cán bộ, một người đảng viên.

Chủ tịch Hồ Chí Minh cũng đề ra cách ứng xử đối với các hạng đảng viên. Đối với những người không chịu nổi khó nhọc, không chịu nổi kỷ luật nghiêm khắc của Đảng mà xin ra khỏi Đảng thì Đảng vẫn bằng 
lòng để họ ra. Đảng chỉ yêu cầu họ không lộ bí mật của Đảng, không phản Đảng, không phá hoại Đảng. Như thế thì Đảng vẫn giữ cảm tình thân thiện với họ" [4; 294]. Tháng 3 năm 1947, Chủ tịch Hồ Chí Minh gửi thư cho các tổ chức Đảng, đề cập đến căn bệnh của chủ nghĩa cá nhân và các biện pháp đấu tranh với căn bệnh ấy. Tuy nhiên, qua thực tế thì ở nhiều tổ chức Đảng biểu hiện của chủ nghĩa cá nhân không được hạn chế, mà còn có xu hướng gia tăng. Vì vậy, trong tác phẩm Sửa đổi lối làm việc Chủ tịch Hồ Chí Minh chỉ rõ những khuyết điểm, sai lầm và cách khắc phục những biểu hiện của chủ nghĩa cá nhân đối với cán bộ, đảng viên. Chủ nghĩa cá nhân là nguyên nhân gây ra những căn bệnh vô cùng nguy hiểm trong Đảng. Những bệnh do chủ nghĩa cá nhân sinh ra đó là: Bệnh tham lam, bệnh lười biếng, bệnh kiêu ngạo, bệnh hiếu danh, thiếu kỷ luật, óc hẹp hòi, óc địa phương, óc lãnh tụ. Chủ tịch Hồ Chí Minh cũng đề cập tới một số căn bệnh nguy hiểm khác như: Bệnh hữu danh vô thực, kéo bè kéo cánh, cận thị, cá nhân, lười biếng, bệnh tị nạnh, xu nịnh, a dua. Từ việc chỉ ra những khuyết điểm, sai lầm trên, Chủ tịch Hồ Chí Minh chủ trương phải bình tĩnh tìm ra nguyên nhân sai lầm và cách sửa chữa khuyết điểm. Cách sữa chữa tốt nhất những khuyết điểm mà cán bộ, đảng viên mắc phải, theo Hồ Chí Minh là thiết thực phê bình và tự phê bình: Trong công tác, trong tranh đấu, trong huấn luyện, các đảng viên, các cán bộ, cần phải luôn luôn tự hỏi mình, tự kiểm điểm mình và đồng chí mình. Luôn luôn dùng và khéo dùng cách phê bình và tự phê bình, thì khuyết điểm nhất định hết dần, ưu điểm nhất định thêm lên và Đảng ta nhất định thắng lợi” $[4 ; 305]$.

\subsubsection{Cách lãnh đạo của Đảng}

Chủ tịch Hồ Chí Minh đã chỉ ra rất cụ thể cách lãnh đạo của Đảng gồm các nội dung: Lãnh đạo và kiểm soát, lãnh đạo như thế nào, học hỏi quần chúng nhưng không theo đuôi quần chúng.

Muốn cho công việc thành công, thì đội ngũ cán bộ, đảng viên của Đảng phải có năng lực lãnh đạo và kiểm soát tốt. Nói năng lực lãnh đạo của cán bộ, đảng viên thực chất là bàn đến khả năng tổ chức và động viên quần chúng thực hiện đường lối, chủ trương, chính sách của Đảng và Nhà nước. Để đảm nhận tốt vai trò lãnh đạo của mình, Người đặt ra yêu cầu cho người lãnh đạo là: "không nên kiêu ngạo mà nên thấu hiểu" [4; 325]. Theo Hồ Chí Minh, lãnh đạo không phải chỉ là lãnh đạo quần chúng mà còn phải học hỏi quần chúng, phải dựa vào dân chúng, không được xa rời dân chúng, phải lắng nghe ý kiến của dân chúng, phải học dân chúng, phải hiểu dân chúng, phải hỏi dân chúng. Bởi vì dân chúng chính là người trực tiếp nhận kết quả từ sự lãnh đạo, từ đường lối, chủ trương của Đảng, vì dân chúng rất nhanh nhạy, dân chúng biết "giải quyết nhiều vấn đề một cách giản đơn, mau chóng, đầy đủ, mà những người tài giỏi, những đoàn thể to lớn, nghĩ mãi không ra" [4;335]. Lãnh đạo không phải chỉ là lãnh đạo quần chúng mà còn phải học hỏi quần chúng, phải thường xuyên tiếp xúc với nhân dân để hiểu nhân dân cần gì, muốn gì, không nên nghe báo cáo một chiều về ý kiến của nhân dân. Theo Người lãnh đạo đúng nghĩa là: "Phải quyết định mọi vấn đề một cách cho đúng (...). Phải tổ chức sự thi hành cho đúng (...). Phải tổ chức sự kiểm soát" $[4,325]$. Trong vấn đề lãnh đạo và kiểm soát, Hồ Chí Minh chú ý tới vấn đề chọn người và thay người. Theo Hồ Chí Minh, chọn người và thay người cũng là một vấn đề quan trọng trong việc lãnh đạo. Lãnh đạo là một nghệ thuật mà người lãnh đạo có vai trò rất quan trọng. Người lãnh đạo cần phải nhận biết đúng vai trò, trách nhiệm của mình, biết mình cần phải làm gì thì mới có thể lãnh đạo tốt được. Lãnh đạo đi liền với kiểm soát. Kiểm soát tốt thì có thể xử lý tốt mọi công việc của Đảng: "muốn biết các nghị quyết có được thi hành không, thi hành có đúng không; muốn biết ai ra sức làm, ai làm qua chuyện, chỉ có một cách, là khéo kiểm soát " 4 ; 327].

Để lãnh đạo cho tốt, Người chỉ ra hai cách lãnh đạo: Một là liên hợp chính sách chung với sự chỉ đạo riêng; Hai là liên hợp người lãnh đạo với quần chúng.

Hồ Chí Minh yêu cầu, cán bộ, đảng viên của mình trong cách lãnh đạo phải học hỏi kinh nghiệm, phải dựa vào quần chúng nhân dân, trên cơ sở quần chúng để tìm ra cách lãnh đạo của mình, nhưng Người đặt ra yêu cầu cho cán bộ, đảng viên là học hỏi quần chúng, nhưng tuyệt đối không được theo đuôi quần chúng. Trong mỗi một khẩu hiệu, mỗi một công tác, mỗi một chính sách của Đảng, phải dựa vào ý kiến và kinh nghiệm của dân chúng, phải nghe theo nguyện vọng của dân chúng; phải học hỏi và bàn bạc với dân chúng, giải thích cho dân chúng; tin vào dân chúng. Nhưng Đảng tuyệt đối không nên theo đuôi quần chúng. Do đó, Đảng cần khéo tập trung ý kiến của quần chúng, hoá nó thành cái đường lối để lãnh đạo quần chúng. Phải đem cách nhân dân so sánh, xem xét, giải quyết các vấn đề, mà hoá nó thành cách chỉ đạo nhân dân. Phải đưa chính trị vào giữa dân gian. Theo Hồ Chí Minh, nếu Đảng làm được như vậy, chính sách, cán bộ và nhân dân sẽ nhất trí, mà Đảng sẽ phát triển rất mau chóng và vững vàng. 


\subsubsection{Vấn đề cán bộ}

Chủ tịch Hồ Chí Minh nhấn mạnh cán bộ là dây chuyền của bộ máy tổ chức. Nếu dây chuyền không tốt, không chạy thì động cơ có tốt thì toàn bộ bộ máy cũng tê liệt. Cán bộ là những người "đem chính sách của Đảng, của Chính phủ giải thích cho dân chúng hiểu rõ và thi hành. Đồng thời đem tình hình của dân chúng báo cáo cho Đảng, cho Chính phủ hiểu rõ, để đặt chính sách cho đúng" [4; 309]. Nếu cán bộ kém thì chủ trương, chính sách của Đảng dù đúng, hay, phù hợp đến mấy cũng không thể thực hiện được. Trong tác phẩm Sửa đổi lối làm việc, Chủ tịch Hồ Chí Minh khẳng định cán bộ là cái gốc của mọi công việc. Công việc thành công hoặc thất bại đều do cán bộ tốt hay kém, có cán bộ tốt việc gì cũng xong. Vì vậy, Đảng phải nuôi dạy cán bộ như người làm vườn vun trồng những cây cối quý báu. Phải trọng nhân tài, trọng cán bộ, trọng mỗi một người có ích cho công việc chung của chúng ta. Cán bộ còn được Chủ tịch Hồ Chí Minh ví là "tiền vốn của Đoàn thể". Vấn đề cán bộ là một công tác rất trọng yếu, rất cần kíp của Đảng. Đảng muốn có đội ngũ cán bộ tốt, phải chú trọng đến công tác cán bộ. Chính vì vậy, khi xây dựng đội ngũ cán bộ, Đảng cần phải phát huy những tài năng của cán bộ, không được dìm cán bộ có tài, đặt cán bộ vào đúng công việc thích hợp, dùng người đúng chỗ, đúng việc.

Theo Hồ Chí Minh, công tác cán bộ gồm những vấn đề cơ bản: Tuyển chọn, đào tạo, huấn luyện, đánh giá, sử dụng và chính sách đối với cán bộ. Những vấn đề: Tuyển chọn, đào tạo, huấn luyện, đánh giá, sử dụng và chính sách đối với cán bộ như một "dây chuyền" hoạt động trong công tác cán bộ của Đảng. Để "dây chuyền" trong công tác cán bộ của Đảng được thực hiện tốt, cần có chuẩn mực cụ thể, thái độ công minh, khách quan, toàn diện, biện chứng, lịch sử, cụ thể. Việc đánh giá cán bộ, đảng viên của Đảng phải bao quát những ưu điểm và thành tích, nhưng cũng thẳng thắn chỉ ra những khuyết điểm cần sửa chữa. Chủ tịch Hồ Chí Minh nêu lên 6 việc phải làm khi dạy và dùng cán bộ: Phải biết rõ cán bộ, phải cất nhắc cán bộ một cách cho đúng, phải khéo dùng cán bộ, phải phân phối cán bộ cho đúng, phải giúp cán bộ cho đúng, phải giữ gìn cán bộ.

Muôn việc thành công hay thất bại là do cán bộ tốt hay kém. Vì vậy, Đảng phải đào tạo, dạy, chăm sóc, quan tâm đến cán bộ như người làm vườn vun trồng những cây cối quý báu; trọng nhân tài, trọng cán bộ, trọng mỗi một người có ích cho công việc chung của Đảng, của đất nước. Đảng phải biết rõ cán bộ, xem xét cán bộ để tìm ra những cán bộ mới đủ đức và tài, mặt khác những cán bộ thoái hóa, biến chất sẽ "lòi ra”. Hiểu rõ cán bộ phải xem xét kỹ lưỡng cả một quá trình hoạt động, toàn bộ công việc không nên chỉ xem xét bề ngoài, chỉ xét một lúc, một việc của cán bộ: "Một người cán bộ khi trước có sai lầm, không phải vì thế mà sai lầm mãi. Cũng có cán bộ đến nay chưa bị sai lầm, nhưng chắc gì sau này không phạm sai lầm? Quá khứ, hiện tại và tương lai của mọi người không phải luôn giống nhau" [4; 317-318]. Khi dùng cán bộ cần đặt đúng người, đúng việc để phát huy tốt năng lực, sở trường của cán bộ. Trong mỗi con người, ai cũng có ưu điểm, khuyết điểm, cái hay, cái dở, cái tốt, cái chưa tốt. Khéo dùng cán bộ sẽ phát huy được điểm mạnh, ưu điểm, hạn chế điểm yếu, khuyết điểm, tránh được tình trạng: "thợ rèn thì bảo đi đóng tủ, thợ mộc thì bảo đi rèn dao. Thành thử hai người đều lúng túng. Nếu biết tuỳ tài mà dùng người, thì hai người đề̀u thành công". Khéo dùng cán bộ Đảng cần phải tin cán bộ; khéo kế thừa, bổ sung giữa thế hệ cán bộ "già" và cán bộ "trẻ”, phải tiếp thu, lắng nghe, góp ý, phê bình từ cấp dưới. Chủ tịch Hồ Chí Minh cũng lưu ý, khi dùng cán bộ cần phải có lòng thân ái mà giúp đỡ, lãnh đạo cán bộ. Giúp họ sửa chữa những chỗ sai lầm. Khen ngợi họ lúc họ làm được việc. Và phải luôn luôn kiểm soát cán bộ. Cán bộ khi sử dụng, bố trí nhân sự vào công việc cụ thể cần tránh 3 căn bệnh: 1 . Ham dùng người bà con, anh em quen biết, bầu bạn, cho họ là chắc chắn hơn người ngoài. 2 . Ham dùng những kẻ khéo nịnh hót mình, mà chán ghét những người chính trực. 3 . Ham dùng những người tính tình hợp với mình, mà tránh những người tính tình không hợp với mình. Để cán bộ phát huy được phẩm chất, năng lực, yên tâm làm việc, yêu thích công việc, ham làm việc, Đảng cần phải đào tạo một đội ngũ cán bộ "cả gan nói, cả gan đề ra ý kiến", "có gan phụ trách, có gan làm việc". Nếu đào tạo ra "một mớ cán bộ nhát gan, dễ bảo "đập đi, hò đứng", không dám phụ trách. Như thế là một việc thất bại cho Đảng" [4;320].

Những tư tưởng và quan điểm của Chủ tịch Hồ Chí Minh về cán bộ, về đánh giá, sử dụng cán bộ trong tác phẩm Sưa đổi lối làm việc là kết tinh truyền thống của cha ông trong lịch sử, là đỉnh cao của "nghệ thuật" hay "phương sách" dùng người. Những tư tưởng đó đã trở thành những bài học, những nguyên tắc trong trong công tác cán bộ của Đảng. Nhờ đó mà Đảng và Chủ tịch Hồ Chí Minh đã tập hợp được nhiều "hiền tài”, thu hút được nhiều nhân sĩ yêu nước, quy tụ được tất cả các lực lượng đoàn kết xung quanh mình làm nên thắng lợi của thắng lợi của Cách mạng Tháng Tám năm 1945, thành lập nhà nước Việt Nam Dân 
chủ cộng hòa; thắng lợi của các cuộc kháng chiến oanh liệt để giải phóng dân tộc, bảo vệ Tổ quốc; thắng lợi của sự nghiệp đổi mới và từng bước đưa đất nước quá độ lên chủ nghĩa xã hội. Những tư tưởng cơ bản và sâu sắc của Chủ tịch Hồ Chí Minh về công tác cán bộ, đã trở thành nhiệm vụ quan trọng, then chốt, thường xuyên của Đảng ta trước đây, cũng như ngày nay. Trong công cuộc đổi mới toàn diện đất nước, càng đòi hỏi phải có một đội ngũ cán bộ có phẩm chất đạo đức cách mạng trong sáng; trình độ lý luận, chuyên môn nghiệp vụ vững vàng, có năng lực tổ chức thực tiễn, ngang tầm với yêu cầu của thời kỳ mới.

\section{3. Đảng Cộng sản Việt Nam vận dụng tư tưởng Hồ Chí Minh về xây dựng Đảng trong tác phẩm Sửa đổi lối làm việc}

Từ khi ra đời, tác phẩm Sưa đổi lối làm việc của Chủ tịch Hồ Chí Minh là một trong những văn kiện quan trọng, là cẩm nang về xây dựng Đảng, xây dựng đội ngũ cán bộ của Đảng Nội dung cơ bản của tác phẩm Sỉa đổi lối làm việc vừa thể hiện sự kế thừa sâu sắc lý luận chủ nghĩa Mác-Lênin về xây dựng Đảng, vừa bổ sung, phát triển làm phong phú thêm nhiều vấn đề mới. Tác phẩm đề cập một cách toàn diện mối quan hệ và những nguyên tắc, phương pháp, cách thức, phong cách làm việc của Đảng; phẩm chất đạo đức cơ bản, quan trọng cần có của đội ngũ cán bộ, đảng viên. Tác phẩm đồng thời chỉ rõ những hạn chế, khuyết điểm, tồn tại phải sửa chữa để Đảng làm tròn trách nhiệm là đội tiên phong của giai cấp, của dân tộc, của nhân dân. Trong bối cảnh toàn Đảng, toàn quân, toàn dân Việt Nam đang đẩy mạnh sự nghiệp công nghiệp hóa, hiện đại hóa, hội nhập quốc tế; những quan điểm của Chủ tịch Hồ Chí Minh trong tác phẩm Sỉa đổi lối làm việc vẫn có giá trị lý luận và giá trị thực tiễn lớn về công tác xây dựng, chỉnh đốn Đảng. Trong quá trình lãnh đạo cách mạng, Đảng Cộng sản Việt Nam luôn kế thừa, bổ sung, vận dụng, làm rõ những quan điểm, tư tưởng của Chủ tịch Hồ Chí Minh về xây dựng, chỉnh đốn Đảng thể hiện ở một số nội dung chủ yếu sau.

\subsection{1. Đẩy mạnh công tác tự phê bình và phê bình, ngăn chặn, đẩy lùi sự suy thoái về tư tưởng chính trị, đạo đức, lối sống, những biểu hiện "tự diễn biển", "tự chuyển hóa" trong nội bộ}

Tự phê bình và phê bình nhằm làm cho mỗi cán bộ, đảng viên ngày càng trở nên hoàn thiện, tổ chức Đảng thêm trong sạch, vững mạnh. Trong thời kỳ đổi mới, Đảng luôn bám sát tình hình thực tiễn, kịp thời chỉ đạo để công tác tự phê bình và phê bình được thực hiện nghiêm túc. Tuy vậy, vẫn có những lúc, những nơi, những cán bộ chưa thật sự làm đúng, đủ, chất lượng công tác tự phê bình và phê bình. Một bộ phận không nhỏ cán bộ, đảng viên suy thoái về tư tưởng chính trị, đạo đức lối sống cũng phần lớn từ nguyên nhân không chịu trang bị cho mình thứ "vũ khí" tự phê bình và phê bình; hoặc được trang bị đầy đủ lý luận về công tác xây dựng Đảng, nắm rõ vị trí, tầm quan trọng mang tính quy luật của công tác này nhưng không sử dụng, không dám sử dụng dẫn đến nói suông, lý luận sáo rỗng, làm cho tính chiến đấu trong Đảng, làm cho vũ khí của Đảng bị dần mai một, kém tác dụng. Nghị quyết số 04-NQ/TW về tăng cường xây dụng, chỉnh đốn Đảng; ngăn chặn, đẩy lùi sự suy thoái về tu tuởng chính trị, đạo đức, lối sống, nhũng biểu hiện "tư diễn biến", "tụ chuyển hoá" trong nội bộ của Ban Chấp hành Trung ương Đảng khóa XII đã chỉ rõ: Trong tự phê bình còn giấu giếm, không dám nhận khuyết điểm; khi có khuyết điểm thì thiếu thành khẩn, không tự giác nhận kỷ luật. Trong phê bình thì nể nang, né tránh, ngại va chạm, thấy đúng không bảo vệ, thấy sai không đấu tranh; lợi dụng phê bình để nịnh bợ, lấy lòng nhau hoặc vu khống, bôi nhọ, chỉ trích, phê phán người khác với động cơ cá nhân không trong sáng [3]. Một số cán bộ, đảng viên, trong đó có cả cán bộ lãnh đạo, quản lý các cấp nhận thức về việc tự kiểm điểm còn nặng tính hình thức, qua loa, chiếu lệ, tự phê bình và phê bình chưa tự giác, chưa gương mẫu và thiếu quyết tâm thực hiện. Một số cán bộ, đảng viên tính chiến đấu yếu, còn tư tưởng "dĩ hòa vi quý". Chưa nhìn nhận đúng mức khuyết điểm và trách nhiệm của mình trước những hạn chế, khuyết điểm của tập thể. Để nâng cao chất lượng tự phê bình và phê bình trong Đảng, các cơ quan, đơn vị cần khắc phục những biểu hiện chưa phù hợp trong phê bình và tự phê bình, khắc phục triệt để lối tư duy chủ quan, duy ý chí, áp đặt khi đề ra đường lối, chính sách và cả những chủ trương, biện pháp cụ thể, tránh trường hợp chủ trương, chính sách ban hành không phù hợp với thực tế hoặc trái với pháp luật như thực tế. Trong những năm gần đây, một số bộ, ngành ở nước ta đã chưa thực sự vận dụng sâu sắc, triệt để quan điểm của Chủ tịch Hồ Chí Minh nên chủ quan, duy ý chí, xa rời thực tế, ban hành những Thông Tư, Quy định trái với thực tiễn đời sống xã hội, gây ảnh hưởng tiêu cực đến đời sống nhân dân. Những quy định "cộng điểm cho bà Mẹ Việt Nam anh hùng, thịt Lợn chỉ được bán trong 8 tiếng, ngực "lép" không được điều khiển phương tiện giao thông, xe chính chủ, giấy chứng minh nhân dân phải ghi tến bố mẹ, quy định về số lượng vòng hoa đi viếng, phạt 5 triệu đồng khi nghe điện thoại ở cây xăng, quy định về đổi giờ học, giờ làm, quy định về đỗ, lưu 
thông xe ngày chẵn lẻ...” còn rất nhiều [5]. Thời gian qua, Bộ tư pháp đã công bố 5.600 văn bản trái pháp luật được phát hiện trong quá trình kiểm tra văn bản do các bộ, ngành, địa phương ban hành gây ra những tác động tiêu cực trong đời sống kinh tế, xã hội. Vậy cơ quan, tổ chức, hay cá nhân nào sẽ chịu trách nhiệm trước những sai phạm đó? Vì vậy, tự phê bình và phê bình cần đẩy mạnh khắc phục tình trạng nể nang, né tránh, ngại va chạm. Thực hiện nghiêm chế độ tự phê bình và phê bình để chỉ rõ và ngăn chặn kịp thời những biểu hiện suy thoái, "tự diễn biến", "tự chuyển hóa" trong nội bộ. Cấp ủy các cấp, nhất là người đứng đầu cấp ủy, cơ quan, đơn vị thực hiện nghiêm trách nhiệm nêu gương, đi đầu trong đấu tranh, ngăn chặn, đẩy lùi sự suy thoái, "tự diễn biến", "tự chuyển hóa" trong nội bộ. Việc thẳng thắn tự kiểm điểm và kiểm điểm trong các tổ chức cơ sở đảng vừa để đề ra giải pháp khắc phục, sửa chữa, đồng thời loại bỏ tính chiếu lệ, nể nang, né tránh. Tìm cách phát hiện sớm hơn nữa nguy cơ tự diễn biến, tự chuyển hóa. Không thể thiếu trách nhiệm nêu gương, sửa chữa trước hết là đội ngũ cán bộ đảng viên chủ chốt, lãnh đạo; đấu tranh triệt để với tình trạng cán bộ miệng nói vô tư mà tham nhũng, cửa quyền, sách nhiễu nhân dân.

Đảng Cộng sản Việt Nam là Đảng cầm quyền, trong đội ngũ đảng viên của Đảng, bên cạnh những đảng viên tiên phong, gương mẫu được nhân dân tin tưởng, đã xuất hiện một bộ phận không nhỏ đảng viên suy thoái về tư tưởng chính trị, đạo đức, lối sống, làm ảnh hưởng lớn đển uy tín của Đảng và là một trong những nguy cơ ảnh hưởng trực tiếp đến vị thế cầm quyền của Đảng. Chính vì vậy, để xây dựng Đảng ngày càng trong sạch, vững mạnh đáp ứng yêu cầu của công cuộc đổi mới, Đảng đã đề ra nhiều Nghị quyết nhằm đẩy mạnh công tác xây dựng Đảng. Ngày 16-1-2012, Hội nghị lần thứ tư Ban Chấp hành Trung ương Đảng khóa XI đã ban hành Nghị quyết số 12-NQ/TW "Một số vấn đề cấp bách về xây dụng Đảng hiện nay", trong đó xác định một trong ba vấn đề cấp bách cần tập trung giải quyết là đấu tranh, ngăn chặn, đẩy lùi tình trạng suy thoái về tư tưởng chính trị, đạo đức, lối sống trong đội ngũ cán bộ, đảng viên, trước hết là cán bộ lãnh đạo, quản lý các cấp. Đây cũng được xác định "là vấn đề trọng tâm, xuyên suốt và cấp bách nhất". Nghị quyết Trung ương 4 khóa XII của Đảng đã đề ra yêu cầu, nhiệm vụ xây dựng, chỉnh đốn Đảng với các nhóm giải pháp cơ bản, trong đó nhấn mạnh việc đấu tranh ngăn chặn, đẩy lùi sự suy thoái về tư tưởng chính trị, đạo đức, lối sống, những biểu hiện "tự diễn biến", "tự chuyển hóa" trong nội bộ. Đặc biệt, trong nhóm nhiệm vụ, giải pháp về công tác chính trị tư tưởng, tự phê bình và phê bình, Nghị quyết Trung ương 4, khóa XII nêu rõ: "Thực hiện nghiêm túc, có hiệu quả việc học tập và làm theo tư tường, đạo đức, phong cách Hồ Chí Minh theo Chỉ thị số 05-CT/TW, ngày 15-5-2016 của Bộ Chính trị’"[3]. Do đó, đẩy mạnh học tập và làm theo tư tưởng, đạo đức, phong cách Hồ Chí Minh theo Chỉ thị 05 của Bộ Chính trị chính là một trong những giải pháp quan trọng về xây dựng Đảng. Mỗi cán bộ đảng viên phải thường xuyên học tập lý luận, sửa chữa các khuyết điểm.

Sự nghiệp đổi mới, xây dựng và bảo vệ Tổ quốc của nước ta đang diễn ra trong sự vận động của lịch sử thế giới đương đại với nhiều diễn biến phức tạp, khó lường. Nhiều vấn đề thực tiễn bức thiết đòi hỏi phải được làm sáng tỏ; nhiều vấn đề lý luận cần được bổ sung, phát triển và hoàn thiện. Trong khi đó, "Công tác tư tưởng còn nhiều bất cập và thiếu tính thuyết phục, tính chiến đấu. Công tác lý luận chưa làm sáng tỏ được một số vấn đề lý luận quan trọng trong công cuộc đổi mới” [1; 48]. Đáp ứng những yêu cầu tình hình và nhiệm vụ của thời kỳ mới, Đại hội XII của Đảng khẳng định: cần phải chú trọng xây dựng Đảng về chính trị. Kiên định chủ nghĩa Mác - Lênin, tư tưởng Hồ Chí Minh, vận dụng sáng tạo và phát triển phù hợp với thực tiễn Việt Nam; kiên định mục tiêu độc lập dân tộc và chủ nghĩa xã hội; kiên định đường lối đổi mới... và đổi mới công tác tư tưởng, lý luận. Tiếp tục đổi mới nội dung, phương thức, nâng cao hơn nữa tính chiến đấu, tính thuyết phục, hiệu quả của công tác tư tưởng...; đẩy mạnh tuyên truyền, học tập chủ nghĩa Mác-Lênin, tư tưởng Hồ Chí Minh, quan điểm, đường lối của Đảng, chính sách, pháp luật của Nhà nước. Tuy nhiên, một số cán bộ đảng viên trong Đảng còn nhận thức sai lệch về ý nghĩa, tầm quan trọng của lý luận và học tập lý luận chính trị; lười học tập chủ nghĩa Mác-Lênin, tư tưởng Hồ Chí Minh, chủ trương, đường lối, nghị quyết của Đảng, chính sách, pháp luật của Nhà nước. Chừng nào những biểu hiện suy thoái về tư tưởng chính trị như: Hoài nghi, thiếu tin tưởng vào chủ nghĩa Mác-Lênin, tư tưởng Hồ Chí Minh; không kiên định con đường đi lên chủ nghĩa xã hội; phụ họa theo những nhận thức lệch lạc, quan điểm sai trái; nhận thức sai lệch về ý nghĩa, tầm quan trọng của lý luận và học tập lý luận chính trị; lười học tập chủ nghĩa Mác-Lênin, tư tưởng Hồ Chí Minh; ngại học tập, nghiên cứu chủ trương, đường lối, nghị quyết của Đảng, chính sách, pháp luật của Nhà nước; "tự diễn biến", "tự chuyển hoá" trong nội bộ",v.v.. vẫn còn, thì chừng đó, nguy cơ về sự suy thoái từ bên trong, quá trình tự biến đổi 
về tư tưởng chính trị, đạo đức, lối sống của cán bộ, đảng viên theo chiều hướng tiêu cực, làm suy giảm nghiêm trọng niềm tin vào chủ nghĩa Mác-Lênin, tư tưởng Hồ Chí Minh, chủ trương, đường lối của Đảng, chính sách, pháp luật của Nhà nước vẫn hiện hữu... Do đó, phải chủ động phòng, chống và ngăn chặn kịp thời, triệt để những biểu hiện suy thoái này.

Toàn Đảng, toàn quân, toàn dân ta đang triển khai thực hiện Nghị quyết Trung ương 4 khóa XII về tăng cường xây dưng, chỉnh đốn Đảng; ngăn chặn đẩy lùi sụ suy thoái về tu tưởng chính trị, đạo đức, lối sống, nhũng biểu hiện "tư diễn biến", "tư chuyển hóa" trong nội bộ. Do vậy, mỗi đảng viên cán bộ phải nhận thức đúng đắn vai trò của lý luận và đổi mới việc giáo dục lý luận; phải khắc phục cho được bệnh coi thường lý luận, lý luận suông, sách vở, giáo điều, phải học tập lý luận chính trị một cách thiết thực, tránh hình thức, qua loa, đại khái....Vận dụng tốt tư tưởng Hồ Chí Minh trong công tác xây dựng Đảng về tư tưởng, chính trị thực chất là bảo vệ vững chắc nền tảng tư tưởng của Đảng là chủ nghĩa Mác-Lênin, tư tưởng Hồ Chí Minh; nâng cao trình độ lý luận cho mỗi cán bộ, đảng viên của Đảng; đề ra những chủ trương, đường lối phù hợp với thực tiễn. Đây không chỉ là nhiệm vụ trước mắt mà còn nhiệm vụ nhất quán, thường xuyên và lâu dài. Công tác lý luận phải góp phần bảo vệ vững chắc nền tảng tư tưởng của Đảng, phê phán các quan điểm sai trái, luận điệu xuyên tạc, làm thất bại mọi âm mưu, thủ đoạn chống phá, nhất là âm mưu "diễn biến hòa bình" của các thế lực thù địch; chống những biểu hiện "tự diễn biến", "tự chuyển hóa" trong nội bộ; củng cố và phát huy sự đoàn kết, thống nhất trong Đảng, sự đồng thuận trong xã hội; góp phần giữ vững ổn định chính trị, bảo đảm môi trường hòa bình, ổn định cho sự nghiệp xây dựng, bảo vệ và phát triển bền vững đất nước.

\subsubsection{Xây dựng đội ngũ cán bộ của Đảng đủ sức đáp ứng yêu cầu của sự nghiệp đổi}

Bước vào thời kỳ toàn cầu hóa, hội nhập và phát triển, uy tín, vị thế của Đảng được khẳng định và nâng cao trong quần chúng nhân dân. Tuy nhiên, môi trường trong nước, khu vực và thế giới có biến động phức tạp, đòi hỏi Đảng phải đổi mới phương thức lãnh đạo, đẩy mạnh hơn công tác xây dựng Đảng nhằm nâng cao uy tín, năng lực và sức chiến đấu của Đảng. Muốn đẩy mạnh công tác xây dựng Đảng, Đảng phải quán triệt tư tưởng Hồ Chí Minh về những nội dung cơ bản của công tác xây dựng Đảng, đào tạo, bồi dưỡng, sử dụng cán bộ trong tình hình mới.

Chủ tịch Hồ Chí Minh khẳng định: Cán bộ là gốc của mọi công việc. Cán bộ là những người đem chính sách của Đảng, của Chính phủ giải thích cho dân chúng hiểu rõ và thi hành. Đồng thời đem tình hình của dân chúng báo cáo cho Đảng, cho Chính phủ hiểu rõ, để đặt chính sách cho đúng. Muôn việc thành công hoặc thất bại, đều do cán bộ tốt hoặc kém. Bất cứ công việc gì thiếu cán bộ, khó thực hiện được. Vì vậy, Chủ tịch Hồ Chí Minh coi vấn đề cán bộ và công tác cán bộ là một trong những vấn đề then chốt quyết định sự thành bại của cách mạng, là công tác gốc của Đảng. Trong tác phẩm Sưa đổi lối làm việc, Chủ tịch Hồ Chí Minh chỉ ra những căn bệnh, yếu kém của đội ngũ cán bộ, đảng viên và tác hại của nó đối với đảng cầm quyền; chỉ rõ nhiệm vụ sửa đổi lối làm việc để chỉnh đốn lại Đảng, làm cho Đảng "mạnh khỏe, chắc chắn", làm cho đội ngũ cán bộ, đảng viên xứng đáng với vai trò tiền phong và gắn bó mật thiết với nhân dân.

Kế thừa, vận dụng sáng tạo tư tưởng Hồ Chí Minh về cán bộ và công tác cán bộ trong tác phẩm Sủa đổi lối làm việc, ở mỗi thời kỳ, mỗi giai đoạn lịch sử, Đảng Cộng sản Việt Nam đã đề ra nhiều chủ trương, quan điểm về chính sách đào tạo, bồi dưỡng và sử dụng cán bộ. Nghị quyết Trung ương 3 , khóa VIII của Đảng xác định: Cán bộ là nhân tố quyết định sự thành bại của cách mạng, là then chốt trong then chốt của công tác xây dựng Đảng. Nhận thức rõ vai trò, vị trí của công tác cán bộ, trải qua nhiều kỳ Đại hội và hội nghị Ban Chấp hành Trung ương Đảng, đến Đại hội XII của Đảng, nội dung, phương pháp, cách làm về công tác cán bộ có nhiều đổi mới và tiển bộ ở từng khâu, từng việc phù hợp luôn bám sát nhiệm vụ chính trị của Đảng. Trên cơ sở những thành tựu đã đạt được về công tác cán bộ, Đại hội XII của Đảng khẳng định: "Tập trung xây dựng đội ngũ cán bộ, nhất là đội ngũ cán bộ cấp chiến lược, đủ năng lực và phẩm chất, ngang tầm nhiệm vụ. Có cơ chế, chính sách phát hiện, thu hút, sử dụng nhân tài” [2;195].

Trong công cuộc đổi mới, thực hiện chiến lược cán bộ trong thời kỳ đẩy mạnh sự nghiệp công nghiệp hóa, hiện đại hóa đất nước; đội ngũ cán bộ các cấp từ Trung ương xuống địa phương của Đảng không ngừng kiện toàn, được đào tạo cả về chính trị, tư tưởng, chuyên môn nghiệp vụ. Chất lượng đội ngũ cán bộ từng bước được nâng cao, cơ bản đảm bảo tính kế thừa, ổn định, đổi mới và phát triển. Đội ngũ cán bộ của Đảng đã có nhiều cán bộ tuổi đời còn rất trẻ, có phẩm chất, năng lực chuyên môn tốt. Đây chính là nguồn cán bộ kế cận, lãnh đạo đất nước với tư duy mới, dám nghĩ, dám làm, dám chịu trách nhiệm, dám 
đương đầu với những thách thức trong quá trình hội nhập. Tuy nhiên, trong quá trình thực hiện nghị quyết Đại hội XII, do chưa lường hết được những tác động của mặt trái cơ chế thị trường, hội nhập quốc tế; một bộ phận cán bộ, đảng viên vẫn mắc phải những khuyết điểm, những căn bệnh trong tác phẩm Sưa đổi lối làm việc Chủ tịch Hồ Chí Minh đã chỉ ra. Những căn bệnh của Đảng cầm quyền, của cán bộ, đảng viên Chủ tịch Hồ Chí Minh đã phát hiện, cảnh báo từ trong tác phẩm Sứa đổi lối làm việc, đến nay vẫn còn tồn tại, thậm chí có phần phức tạp hơn trước, khó sửa chữa hơn trước. Một bộ phận không nhỏ cán bộ, đảng viên, kể cả một số cán bộ chủ chốt các cấp, yếu kém cả về phẩm chất và năng lực; thiếu tính chiến đấu và tinh thần bảo vệ quan điểm, đường lối của Đảng, chính sách, pháp luật của Nhà nước, giảm sút lòng tin, phai nhạt lý tưởng; một số ít có biểu hiện bất mãn, mất lòng tin, nói và làm trái với quan điểm, đường lối của Đảng, vi phạm nguyên tắc tổ chức và hoạt động của Đảng, vi phạm pháp luật của Nhà nước. Bệnh cơ hội, chủ nghĩa cá nhân trong một bộ phận cán bộ, đảng viên có chiều hướng gia tăng; vẫn còn tình trạng "chạy chức", "chạy quyền", "chạy tội”, "chạy bằng cấp", "chạy phiếu bầu", "chạy phiếu tín nhiệm", "chạy luân chuyển".... Can thiệp không đúng thẩm quyền, trách nhiệm, trái quy định vào công tác cán bộ; đề bạt, bổ nhiệm, bố trí cán bộ không đủ tiêu chuẩn, điều kiện theo quy định, nhất là đối với người nhà, người thân. Những biểu hiện cụ thể trên, là một trong những nguy cơ liên quan đến sự sống còn của Đảng, của chế độ. Thực trạng trên đã được Nghị quyết Trung ương 4 khóa XII "về tăng cường xây dựng, chỉnh đốn Đảng; ngăn chặn, đẩy lùi sự suy thoái về tư tưởng chính trị, đạo đức, lối sống, những biểu hiện "tự diễn biến", "tự chuyển hóa" trong nội bộ" chỉ rõ: "Tình trạng suy thoái về tư tưởng chính trị, đạo đức, lối sống của một bộ phận không nhỏ cán bộ, đảng viên chưa bị đẩy lùi, có mặt, có bộ phận còn diễn biến tinh vi, phức tạp hơn; tham nhũng, lãng phí, tiêu cực vẫn còn nghiêm trọng, tập trung vào số đảng viên có chức vụ trong bộ máy nhà nước...". Nghị quyết khẳng định, phải "Kiên quyết sàng lọc, miễn nhiệm, thay thế, cho từ chức đối với cán bộ làm việc kém hiệu quả, không hoàn thành nhiệm vụ, yếu về năng lực, kém về phẩm chất đạo đức, tín nhiệm thấp mà không chờ hết nhiệm kỳ, hết tuổi công tác, nhất là cán bộ lãnh đạo, quản lý và người đứng đầu" [3]. Trong nhiệm kỳ Đại hội XII của Đảng (2016-2021), nhiều cán bộ chủ chốt, cán bộ là ủy viên Bộ Chính trị phải thi hành kỷ luật. 4 ủy viên trung ương khóa XII bị kỷ luật, cách hết các chức vụ trong Đảng khi tuổi còn rất trẻ như Nguyễn Xuân Anh. Trường hợp điều động, bổ nhiệm nhân sự cán bộ tại tỉnh Bắc Ninh trong tháng 7 năm 2020 là một ví dụ điển hình. Ngày 22 tháng 7 năm 2020, Ban Thường vụ Tỉnh ủy Bắc Ninh có quyết định chỉ định Bí thư Tỉnh đoàn Bắc Ninh Nguyễn Nhân Chinh giữ chức Bí thư Thành ủy Bắc Ninh. Ông Nguyễn Nhân Chinh là con trai ông Nguyễn Nhân Chiến, Bí thư Tỉnh ủy Bắc Ninh đương nhiệm. Việc Ban Thường vụ Tỉnh ủy Bắc Ninh chỉ định ông Nguyễn Nhân Chinh giữ chức Bí thư Thành ủy Bắc Ninh đã gây ra dư luận trái chiều. Sau đó, Ban Tổ chức Trung ương đã có văn bản yêu cầu Ban Thường vụ Tỉnh ủy Bắc Ninh xem xét lại các quyết định về nhân sự theo thẩm quyền. Sáng ngày 6 tháng 8 năm 2020, Ban Thường vụ Thành ủy Bắc Ninh tổ chức hội nghị Ban Chấp hành Đảng bộ Thành phố để công bố quyết định của Ban Thường vụ Tỉnh ủy Bắc Ninh về công tác cán bộ. Ông Nguyễn Nhân Chinh cũng được điều động, bổ nhiệm làm Phó giám đốc Sở Lao động-Thương binh-Xã hội tỉnh Bắc Ninh [6]. Việc bổ nhiệm cán bộ, sau đó gặp phải phản ứng của dư luận rồi điều chuyển sang vị trí khác là bài học rất lớn cho các địa phương, các cấp, các ngành về công tác cán bộ.

Từ thực tế trên đặt ra yêu cầu công tác lựa chọn cán bộ thực hiện đúng các quy trình một cách chính xác, hợp lý. Phải tham khảo sát, đánh giá về chất lượng nhân sự cán bộ. Các cấp ủy cần thực hiện nghiêm túc, có hiệu quả các quy định của Đảng về công tác cán bộ nhất là công tác nhân sự. Người đứng đầu cấp ủy phải thật sự gương mẫu, đặt sự nghiệp chung của Đảng, của nhân dân lên trên hết, trước hết; thật sự công tâm, khách quan, trong sáng, chấp hành nghiêm các quy chế, quy định của Đảng trong quá trình giới thiệu,lựa chọn nhân sự, bảo đảm dân chủ, công khai, minh bạch, đúng người, đúng việc. Nghiêm cấm việc hợp thức hóa các quy trình nhằm thực hiện ý đồ cá nhân, chấm dứt tình trạng đúng quy trình, quy định, nhưng không chọn đúng người, đúng việc trong công tác nhân sự, công tác cán bộ. Tổng Bí thư-Chủ tịch nước Nguyễn Phú Trọng khi đề cập đến vấn đề tổ chức và chuẩn bị Đại hội Đảng bộ các cấp đã nhấn mạnh: Đánh giá đúng tình hình bao giờ cũng là một việc khó, đòi hỏi phải có bản lĩnh chính trị vững vàng, phương pháp khoa học, thái độ chân thành, nghiêm túc, trung thực của từng cấp ủy, tổ chức Đảng và cá nhân người đứng đầu. Hiện nay, toàn Đảng toàn quân và toàn dân đang thực hiện Chỉ thị số 35 của Bộ Chính trị về Đại hội Đảng bộ các cấp tiến tới Đại hội Đại biểu toàn quốc lẩn thứ XIII của Đảng thì công tác cán bộ càng phải tiến hành chặt chẽ, đúng quy định nhất là về công tác nhân sự. Nếu không làm 
tốt các yêu cầu về công tác cán bộ theo Chủ tịch Hồ Chí Minh và tuân thủ nghiêm các quy chế, quy định của Đảng trong quá trình giới thiệu, lựa chọn nhân sự, bảo đảm dân chủ, công khai, minh bạch, đúng người, đúng việc thì công tác cán bộ còn vấp phải những hạn chế như trong nhiệm kỳ Đại hội XII vừa qua.

Những tư tưởng của Hồ Chí Minh về cán bộ, công tác cán bộ trong Sửa đổi lối làm việc có giá trị lý luận và thực tiễn to lớn, định hướng cho Đảng trong việc tạo nguồn, quy hoạch, tuyển chọn, đào tạo, bố trí, sử dụng đội ngũ cán bộ của Đảng. Thực hiện tốt các quy trình trên sẽ hạn chế một phần tiêu cực, xây dựng được đội ngũ cán bộ đủ đức, đủ tài đảm đương sự nghiệp cách mạng của Đảng, của dân tộc.

\section{KẾT LUẬN}

Hồ Chí Minh viết tác phẩm Sủa đổi lối làm việc với mục đích để xây dựng cách lãnh đạo và lề lối làm việc, làm cẩm nang cho cán bộ đảng viên trong điều kiện Đảng cầm quyền. Đảng Cộng sản Việt Nam là Đảng cầm quyền. Đảng có vai trò lãnh đạo nhân dân kháng chiến chống thực dân đế quốc, giải phóng dân tộc, xây dựng và bảo vệ Tổ quốc. Đảng có trách nhiệm đề ra đường lối, chủ trương, chính sách đúng đắn để lãnh đạo Nhà nước và nhân dân cùng thực hiện, nhưng đồng thời, Đảng cũng phải chịu trách nhiệm trước nhân dân về tất cả những kết quả đúng - sai, thành công - thất bại theo định hướng mà Đảng đã đề ra. Chính vì vậy, Đảng cần phải thực sự trong sạch, vững mạnh. Đội ngũ cán bộ, đảng viên của Đảng phải là những người có tư cách đạo đức trong sáng thì mới xứng với trách nhiệm của Đảng và sự tin tưởng của nhân dân. Ngày nay, trong công cuộc đổi mới đất nước, mỗi cán bộ, đảng viên cần phải nhận thức rõ và sâu sắc về vai trò và tầm quan trọng của việc "sửa đổi" đạo đức, tác phong "lối làm việc" trong Đảng theo tư tưởng của Chủ tịch Hồ Chí Minh, ra sức phấn đấu học tập và rèn luyện không ngừng, để nâng cao tri thức và bản lĩnh chính trị của mình, góp phần xây dựng Đảng ngày càng trong sạch vững mạnh, xây dựng đất nước ngày càng giàu đẹp và văn minh, như ước nguyện của Chủ tịch Hồ Chí Minh.

\section{TÀI LIỆU THAM KHẢO}

[1] Đảng Cộng sản Việt Nam (2006), Văn kiện Đại hội đại biểu toàn quốc lần thứ X, Chính trị quốc gia, Hà Nội.

[2] Đảng Cộng sản Việt Nam (2016), Văn kiện Đại hội đại biểu toàn quốc lần thứ XII, Văn phòng Trung ương Đảng, Hà Nội.

[3] Đảng Cộng sản Việt Nam (2016), "Nghị quyết số 04/NQ-TW ngày 30/10/2016, Hội nghị lần thứ tư Ban Chấp hành Trung ương Đảng (khóa XII) về tăng cường xây dựng, chỉnh đốn Đảng; ngăn chặn, đẩy lùi sự suy thoái về tư tưởng chính trị, đạo đức, lối sống, những biểu hiện "tự diễn biến", "tự chuyển hoá" trong nội bộ", Báo điện tủ Đảng Cộng sản Việt Nam, tại trang http://tulieuvankien.dangcongsan.vn/van-kien-tu-lieu-ve-dang/hoi-nghi-bch-trunguong/khoa-xii/nghi-quyet-so-04nq-tw-ngay-30102016-hoi-nghi-lan-thu-tu-ban-chap-hanh-trung-uong-dang-khoaxii-ve-tang-cuong-xay-dung-chinh-550, truy cập ngày 17/8/2020.

[4] Hồ Chí Minh (2011), Toàn tập, tập 5, Nxb Chính trị quốc gia, Hà Nội.

[5] N.N.T (2020), "Nhũng nội dung chính trong tác phẩm "Sỉa đổi lối làm việc"”, tại trang http://www.vkskh.gov.vn/nhung-noi-dung-chinh-trong-tac-pham-sua-doi-loi-lam-viec-ky-5_1662_387_2_a.html, truy cập ngày 17/8/2020.

[6] “Thành ủy Bắc Ninh có Bí thư mới thay ông Nguyễn Nhân Chinh”, Báo Thanh niên Điện tử, tại trang https://thanhnien.vn/THOI-SU/THANH-UY-BAC-NINH-CO-BI-THU-MOI-THAY-ONG-NGUYEN-NHAN-

CHINH-1261644.HTML, truy cập ngày 17/8/2020.

Ngày nhận bài:18/08/2020

Ngày chấp nhận đăng:23/11/2020 